\title{
Atmosphere-forest Exchange of Ammoniacal Nitrogen in a Subalpine Deciduous Forest in Central Japan during a Summer Week
}

\author{
Kentaro Hayashi*, Kazuhide Matsuda ${ }^{1)}$, Akira Takahashi ${ }^{2)}$ and Ko Nakaya ${ }^{2)}$ \\ Carbon and Nutrient Cycles Division, National Institute for Agro-Environmental Sciences, Tsukuba, Japan \\ ${ }^{1)}$ School of Science and Engineering, Meisei University, Tokyo, Japan \\ ${ }^{2)}$ Central Research Institute of Electric Power Industry, Chiba, Japan \\ *Corresponding author. Tel: +81-29-838-8225, E-mail: kentaroh@affrc.go.jp
}

\begin{abstract}
The present study aimed to investigate the diurnal variations in air concentrations and exchange fluxes of ammoniacal nitrogen $\left(\mathrm{NH}_{\mathrm{x}}\right.$ : ammonia $\left(\mathrm{NH}_{3}\right)$ and particulate ammonium) in a subalpine deciduous forest in central Japan during a week in summer. The $\mathrm{NH}_{3}$ concentrations $\left(0.50 \mu \mathrm{g} \mathrm{N} \mathrm{m}{ }^{-3}\right.$ on average) showed a clear circadian variation, i.e., high and low in the daytime and nighttime, respectively. The concentration of particulate ammonium in the coarse fractions was extremely low, whereas that for the PM2.5 fraction was relatively high $\left(0.55 \mu \mathrm{g} \mathrm{N} \mathrm{m}^{-3}\right.$ on average). The main inorganic ion components of PM2.5 at the study site were ammonium and sulfate. The exchange fluxes of $\mathrm{NH}_{\mathrm{x}}$ were bidirectional. Both the maximum and minimum values occurred in the daytime, i.e., $0.39 \mathrm{mg} \mathrm{N} \mathrm{m}^{-2} \mathrm{hr}^{-1}$ of downward flux and $0.11 \mathrm{mg} \mathrm{N} \mathrm{m}^{-2} \mathrm{hr}^{-1}$ of upward flux for $\mathrm{NH}_{3}$ and $0.25 \mathrm{mg} \mathrm{N} \mathrm{m}^{-2} \mathrm{hr}^{-1}$ of downward flux and $0.13 \mathrm{mg} \mathrm{N}$ $\mathrm{m}^{-2} \mathrm{hr}^{-1}$ of upward flux for PM2.5 ammonium. The exchange fluxes of $\mathrm{NH}_{\mathrm{x}}$ at night could be considered as zero. The mean deposition velocity during the research period was almost zero for both $\mathrm{NH}_{3}$ and PM2.5 ammonium. The atmosphere-forest exchange of $\mathrm{NH}_{\mathrm{x}}$ in the forest during the study period was balanced. The remarkably large deposition of $\mathrm{NH}_{\mathrm{x}}$ was attributable to meteorological events such as showers the night before that thoroughly washed the forest canopy and subsequent clear skies in the morning, which enhanced convection. The cleaning effect of rainfall and the rapid change in convection in the early morning should be monitored to evaluate and generalize the gas and particle exchange in a forest.
\end{abstract}

Key words: Ammonia, Atmosphere-forest exchange, Dry deposition, Emission, Particulate ammonium

\section{INTRODUCTION}

Increases in nitrogen deposition induced by anthropogenic nitrogen emissions have impacts on natural ecosystems, such as acidification, eutrophication, and other related environmental consequences (Hayashi and Yan, 2010; Bouwman et al., 2002; Matson et al., 2002). In this regard, ammonia $\left(\mathrm{NH}_{3}\right)$ is one of the most important forms of nitrogen because it has the largest anthropogenic emissions in the world (47.2 Tg $\mathrm{N} \mathrm{yr}^{-1}$ in the early 1990s), which outweighs those of nitrogen oxides (36.2 $\mathrm{Tg} \mathrm{N} \mathrm{yr}^{-1}$ ) (Galloway et al., 2004). After deposition, $\mathrm{NH}_{3}$ can potentially cause acidification, via proton production that occurs during nitrification, as well as eutrophication, because $\mathrm{NH}_{3}$ is biologically available nitrogen.

Ammonia is also a main precursor of secondary inorganic particles such as particulate ammonium $\left(\mathrm{pNH}_{4}\right)$ (Erisman and Schaap, 2004), which is formed by the condensation of $\mathrm{NH}_{3}$ with acids in the atmosphere. Secondary particles are mostly fine particles classified as PM2.5 (particles with a diameter less than $2.5 \mu \mathrm{m}$ ). PM2.5 can cause health risks for respiratory diseases (Neuberger et al., 2004) and can be transported long distances in the atmosphere due to their relatively long residence time (Niemi et al., 2009). PM2.5 is also related to climate change due to their radiative forcing (IPCC, 2007).

Part of $\mathrm{pNH}_{4}$ can evaporate and then release $\mathrm{NH}_{3}$. The equilibrium between the condensation and evaporation of $\mathrm{pNH}_{4}$ is affected by the chemical forms of $\mathrm{pNH}_{4}$, the air concentrations of relevant species, and temperature. In general, the dominant chemical forms of $\mathrm{pNH}_{4}$ correspond to ammonium sulfate and ammonium nitrate (e.g., Bardouki et al., 2003). For ammonium sulfate, the vapor pressure of sulfate salts is sufficiently low for the condensation of $\mathrm{NH}_{3}$ to ammonium sulfate to be considered irreversible (Nemitz et al., 2004). For ammonium nitrate, both the condensation 
of $\mathrm{NH}_{3}$ and the evaporation of ammonium nitrate, i.e., gas-particle interconversion, can occur (Nemitz and Sutton, 2004; Nemitz et al., 2004; Pryor et al., 2001; van Oss et al., 1998).

Atmospheric deposition is an important process in terms of the nitrogen input to a forest, although excessive loads may have harmful effects. Atmospheric deposition is divided into dry and wet deposition. For ammoniacal nitrogen, dry deposition of $\mathrm{NH}_{3}$ and $\mathrm{pNH}_{4}$ (collectively $\mathrm{NH}_{\mathrm{x}}$ ) occurs in addition to wet deposition of ammonium ions. However, the atmosphere-forest exchange of $\mathrm{NH}_{\mathrm{x}}$ is bidirectional. A forest can be an emitter of $\mathrm{NH}_{3}$ through stomatal emissions, re-evaporation of $\mathrm{NH}_{\mathrm{x}}$ that has deposited onto leaf surfaces (cuticular emission), and soil emissions (Neirynck and Ceulemans, 2008; Andersen et al., 1999; Wyers and Erisman, 1998; Langford and Fehsenfeld, 1992). Condensation of $\mathrm{NH}_{3}$ near the canopy increases and decreases the air concentrations of $\mathrm{pNH}_{4}$ and $\mathrm{NH}_{3}$, respectively, which may cause an apparent emission and deposition of $\mathrm{pNH}_{4}$ and $\mathrm{NH}_{3}$, respectively; the opposite is true for the evaporation of $\mathrm{pNH}_{4}$. Therefore, in terms of the atmosphere-forest exchange of $\mathrm{NH}_{\mathrm{x}}$, dry deposition of $\mathrm{NH}_{\mathrm{x}}$ to the forest, $\mathrm{NH}_{3}$ emissions from the forest, and gas-particle interconversion near the forest canopy are important processes for its quantitative evaluation.

A number of studies regarding the atmosphere-forest exchange of $\mathrm{NH}_{\mathrm{x}}$ have been conducted in North America and Europe. By contrast, little information is available pertaining to East Asia, including Japan, except for several field studies (e.g., Hayashi et al., 2009a). The project of Impacts of Aerosols in East Asia on Plants and Human Health (ASEPH) was launched in 2008. The purpose of the present study, as a part of ASEPH activities, was to investigate the diurnal variations in air concentrations and exchange fluxes of $\mathrm{NH}_{\mathrm{x}}$ over a subalpine deciduous forest in central Japan in summer, when biological activities are at their maximum, as a first step towards accumulating data on the atmosphere-forest exchange of $\mathrm{NH}_{\mathrm{x}}$ in East Asia.

\section{MATERIALS AND METHODS}

\subsection{Site Description}

The study site $\left(36^{\circ} 24^{\prime} \mathrm{N}, 138^{\circ} 35^{\prime} \mathrm{E}, 1,380 \mathrm{~m}\right.$ A.S.L. $)$ was located in a subalpine area, i.e., a cool-temperate deciduous forest on the eastern foot of Mt. Asama, Nagano Prefecture, in central Japan. The forest, with a canopy height of approximately $20 \mathrm{~m}$, stands on nearly flat terrain with a gentle slope of $3^{\circ}$ over a distance of more than $600 \mathrm{~m}$ in the main upwind direction.
The forest is composed mainly of birch (Betula ermanii); other tree species include alder (Alnus hirsuta).

Mt. Asama is an active volcano that emits volcanic gas containing sulfur dioxide $\left(\mathrm{SO}_{2}\right)$. The distance from the crater to the study site is approximately $5 \mathrm{~km}$. There has been no visible damage to the forest at the study site despite occasional exposure to $\mathrm{SO}_{2}$ from the volcano. The net ecosystem exchange (NEE) of carbon dioxide for the forest at the study site $\left(-682 \mathrm{~g} \mathrm{CO}_{2}\right.$ $\mathrm{m}^{-2} \mathrm{yr}^{-1}$ ) (Nakaya, 2008) is on par with the NEE of a similar remote forest of 40-year-old birch in central Japan that is not influenced by volcanic gas $(-598 \mathrm{~g}$ $\mathrm{CO}_{2} \mathrm{~m}^{-2} \mathrm{yr}^{-1}$ ) (Saigusa et al., 2002).

\section{2 Instruments}

The study site had twin walk-up towers with a height of $28 \mathrm{~m}$ from the ground surface. Measurements of the air concentrations were conducted using one tower in the summer from 2 to 8 July 2009. The air concentrations of gases, including $\mathrm{NH}_{3}$, were measured using a filter pack method (EMEP, 2001) with filter holders (NL-O, NILU). A filter pack consisted of five filter holders (Hayashi et al., 2007), in which phosphoric acid impregnated filters were used to collect $\mathrm{NH}_{3}$. The flow rate was $10 \mathrm{~L} \mathrm{~min}^{-1}$. The air concentrations of particles, including $\mathrm{pNH}_{4}$, were measured using aerosol samplers (MCI sampler, Tokyo Dylec Corporation) with a PM2.5 impactor that separated aerosols into coarse particles and PM2.5 (Matsuda et al., 2010), in which glass fiber filters were used to collect particles. The flow rate was $20 \mathrm{~L} \mathrm{~min}^{-1}$. The air concentrations were measured at three heights $(21,24$, and $27 \mathrm{~m}$ from the ground surface). Although the filter pack method has some possible artifacts when determining air concentrations, as reported in Section 2.4, the use of as simple a method as possible is advantageous to encourage future relevant studies in East Asia.

Samplers were replaced at 6:00, 10:00, 14:00, and 18:00; the sampling frequency was thrice during the daytime and once at night. Each of the collected sample filters was sealed as soon as possible in a clean polypropylene test tube with a cap to avoid contamination. The target substances collected on the filter were extracted by ultrasonic extraction with $10 \mathrm{~mL}$ of deionized water and then analyzed using ion chromatography.

A meteorological observation was conducted on the other tower at a height of $28 \mathrm{~m}$ from the ground surface with an ultrasonic anemometer-thermometer (METEK, USA-1) and other meteorological instruments, such as temperature and humidity sensors. Thirty-minute means were recorded to a data logger.

\subsection{Calculation of the Exchange Flux}

A gradient method (Erisman and Draaijers, 1995) 
was applied to determine the exchange flux, $F$ (nmol $\mathrm{m}^{-2} \mathrm{~s}^{-1}$ ). The original equation was modified to calculate the flux as a product of the diffusion velocity, $D$ $\left(\mathrm{m} \mathrm{s}^{-1}\right)$ and the difference in concentration between the two heights, $\Delta c\left(\mathrm{nmol} \mathrm{m}^{-3}\right)$,

$$
F=-u_{*} c_{*}=-D \Delta c,
$$

where $u_{*}$ and $c_{*}$ are the friction velocity $\left(\mathrm{m} \mathrm{s}^{-1}\right)$ and the eddy concentration $\left(c_{*} \equiv\left\{\kappa(z-d) / \varphi_{h}\right\}(\partial c / \partial z)\right.$; nmol m${ }^{-3}$ ), respectively. The terms $\kappa, z, d, \varphi_{h}$, and $c$ are the von Karman's constant $(=0.4)$, the target height $(\mathrm{m})$, the zero plane displacement $(\mathrm{m})$, the stability correction function for heat, and the air concentration $\left(\mathrm{nmol} \mathrm{m}^{-3}\right) . D$ is expressed by,

$$
D=\kappa u_{*}\left\{\ln \left(\zeta_{2} \zeta_{1}^{-1}\right)-\Psi_{h}\left(\zeta_{2}\right)+\Psi_{h}\left(\zeta_{1}\right)\right\}^{-1},
$$

where $\Psi_{h}$ is the integrated stability correction function for heat (Erisman and Draaijers, 1995). The term $\xi$ is the Monin-Obukhov stability parameter defined as $\xi=$ $(z-d) L^{-1}$, where $L$ is the Monin-Obukhov length (m). The subscripts 1 and 2 denote each height $\left(z_{2}>z_{1}\right)$. The value of $d$ was expressed as $80 \%$ of the canopy height $(=16 \mathrm{~m}$ ) (Matsuda et al., 2010).

The exchange fluxes between the heights of 21 and $27 \mathrm{~m}$ were determined. The highest and lowest heights were chosen to maximize the difference in concentration. $D$ was calculated using the 30 -minute means of $u_{*}$ and $L$, and averaged at 4-hour intervals. The exchange flux as a 4-hour mean was then calculated by Eq. (1). The air concentration was assumed to be constant during each sampling period. Although a 12-hour sampling period occurred at night, the exchange flux in the nighttime was also calculated every 4 hours based on the assumption that $c$ was constant over the nighttime.

\section{4 Uncertainty}

The filter pack method has some possible artifacts, e.g., the re-evaporation of particles from the upstream stage filter following a temperature rise (Keck and Wittmaack, 2005; Anlauf et al., 1985). However, Sickles et al. (1999) observed good agreement between results from the filter pack method and those of the annular denuder method for measuring $\mathrm{pNH}_{4}$. Daynight separation was applied to the present study for sampling, which was effective in reducing the artifact via the re-evaporation of particles due to large changes in temperature between daytime and nighttime. The mean coefficients of variation of air concentrations determined by the filter pack method were $7.1 \%$ and $15.1 \%$ for $\mathrm{NH}_{3}$ and $\mathrm{pNH}_{4}$, respectively (Hayashi et $a l ., 2009 b$ ), which were taken into account as the error of the filter pack method in the present study.

The phosphoric acid impregnated filters used to col- lect $\mathrm{NH}_{3}$ had a blank value of $0.13 \pm 0.06 \mu \mathrm{g} \mathrm{N}$ as ammonium per sheet with a diameter of $47 \mathrm{~mm}$, which accounted for $4.2-8.7 \%$ of the total amount of $\mathrm{NH}_{3}$ per sheet sampled in the present study. The glass fiber filters used for collecting coarse particles had a blank value of $0.28 \pm 0.05 \mu \mathrm{g} \mathrm{N}$ as ammonium, and those used for PM2.5 had a blank of $0.13 \pm 0.01 \mu \mathrm{g} \mathrm{N}$, which accounted for around $100 \%$ of the total amount of $\mathrm{pNH}_{4}$ per sheet sampled when the air concentrations of particles were extremely low. The detection limit of ion chromatography, $10 \mu \mathrm{g} \mathrm{L}^{-1}$ as ammonium ion, was sufficiently small to determine the air concentrations of $\mathrm{NH}_{\mathrm{x}}$, which corresponded to $0.03 \mu \mathrm{g} \mathrm{N} \mathrm{m}^{-3}$.

Our previous report (Matsuda et al., 2010) pointed out how little error is induced by calculating the exchange fluxes in the nighttime every 4 hours using the 12-hour mean of the air concentration. This lack of error is attributable to the near-zero concentration differences over time in the nighttime, as described later, which is attributable to the remarkable decreases in air concentrations in the nighttime (Fig. 2). For reference, the absolute value of $\Delta c$ is smaller than $c$. Therefore, the uncertainty of $\Delta c$ seems larger than that of $c$ particularly in the nighttime, when $\Delta c$ is near zero.

Assuming a $10 \%$ error in meteorological observations, the maximum relative errors in $D$ were approximately $20 \%$ and $100 \%$ in the daytime and nighttime, respectively (Miyata, 2001). The gradient method based on the Monin-Obukhov theory is valid within the inertial sub-layer (Businger, 1986). Therefore, Eq. (2) might underestimate $D$ when applied to the roughness sub-layer, e.g., near the canopy, due to an increase in eddy diffusivity within this layer (Matsuda et al., 2010). Wyers and Duyzer (1997) introduced heightdependent correction factors for the use of the gradient method within the roughness sub-layer, although this correction was not used in the present study because of differences in site conditions.

The measurement error of the filter pack method, the measurement-oriented error in $D$, and the standard deviation of $D$ for 4-hour mean were used to calculate the errors of the exchange fluxes in the present study.

\section{RESULTS AND DISCUSSION}

\subsection{Meteorological Conditions}

Fig. 1 shows the meteorological variables. The weather at the study site during the research period was generally cloudy, cool, and humid with occasional drizzle or showers. The mean values of air temperature were 17.3 and $15.4^{\circ} \mathrm{C}$, in the daytime and nighttime, respectively, and the mean values of relative humidity were 86 and 91\% (Matsuda et al., 2010). The high 

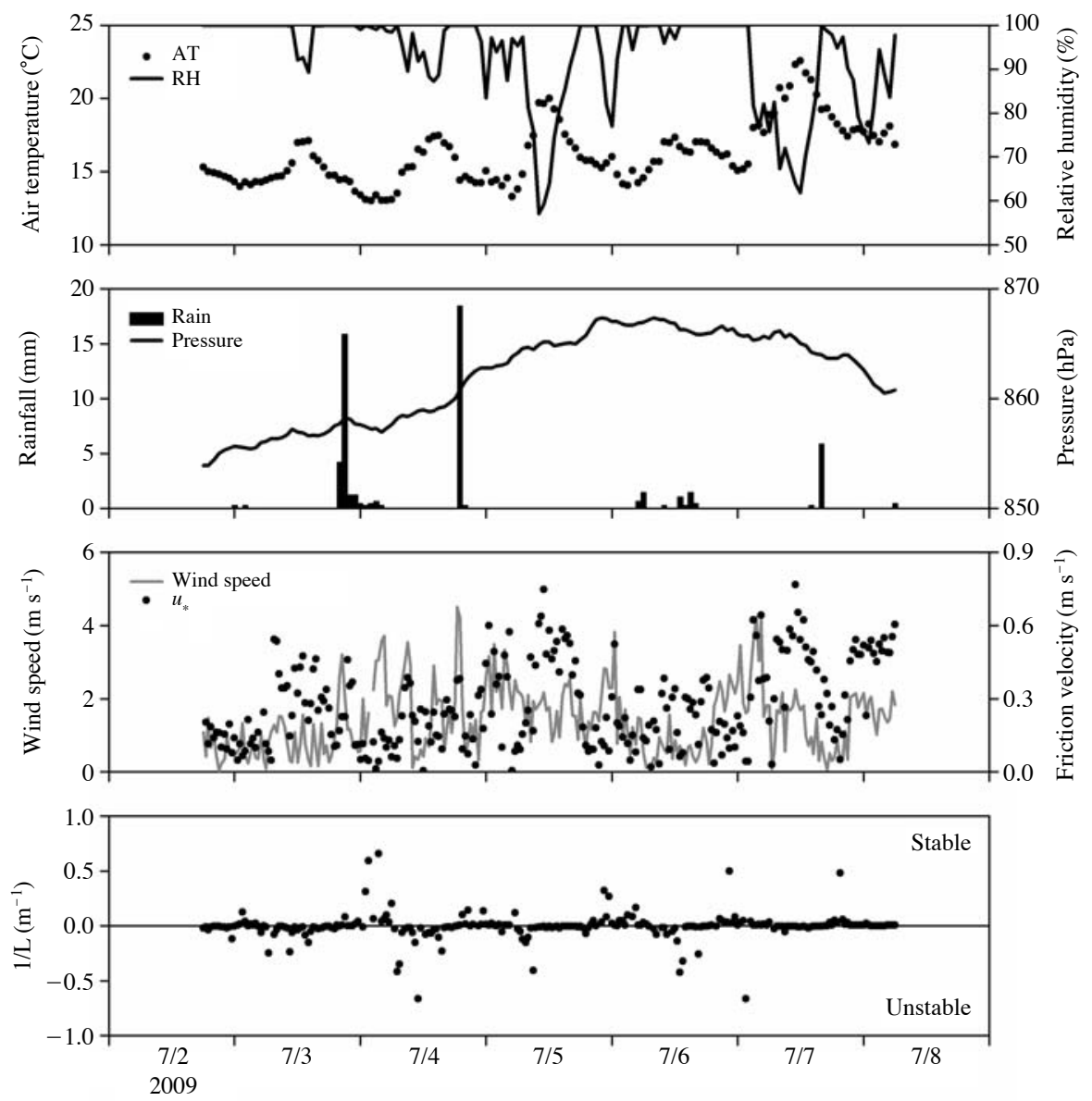

Fig. 1. Meteorological conditions.

relative humidity throughout the whole day made the canopy surface wet, particularly at night. The weather at the study site was clear in the daytime on 5 July 2009 and in the morning on 7 July 2009, when remarkable increases and decreases in the air temperature and relative humidity, respectively, were observed; $u_{*}$ also had relatively high values during these periods (Fig. 1).

\subsection{Air Concentrations}

The air concentrations are expressed as $\mu \mathrm{g} \mathrm{N} \mathrm{m}{ }^{-3}$ at standard temperature and pressure $\left(20^{\circ} \mathrm{C}, 1,013 \mathrm{hPa}\right)$ in the present study. One $\mu \mathrm{g} \mathrm{N} \mathrm{m}{ }^{-3}$ of $\mathrm{NH}_{3}$ or $\mathrm{pNH}_{4}$ equals 1.21 or $1.29 \mu \mathrm{g} \mathrm{m}^{-3}$ of each component, respectively.

Fig. 2 shows the air concentrations of each component at three heights. The range of $\mathrm{NH}_{3}$ concentrations was $0.20-1.1 \mu \mathrm{g} \mathrm{N} \mathrm{m}{ }^{-3}$. The $\mathrm{NH}_{3}$ concentrations had a circadian variation with a nearly constant amplitude, i.e., high in the daytime and low at night. The concentrations of $\mathrm{pNH}_{4}$ as coarse particles were very low, less than $0.2 \mu \mathrm{g} \mathrm{N} \mathrm{m}{ }^{-3}$. Coarse particles are, therefore, excluded from the following discussion. The concentrations of PM2.5 ammonium were relatively high; the maximum concentration was $1.5 \mu \mathrm{g} \mathrm{N} \mathrm{m}{ }^{-3}$. An obvious feature of the pattern in PM2.5 ammonium concentrations was the lack of any circadian variation, especially in contrast to the clear circadian variation of $\mathrm{NH}_{3}$ (Fig. 2). The PM2.5 ammonium concentration seemed to have a longer-term variation, which might be related to the long-range transport of PM2.5.

Table 1 summarizes the air concentrations at each height. The daytime and nighttime means of the $\mathrm{NH}_{3}$ concentrations ( \pm standard deviation, $27 \mathrm{~m}$ height) were $0.77 \pm 0.20$ and $0.24 \pm 0.05 \mu \mathrm{g} \mathrm{N} \mathrm{m}^{-3}$, respectively. The daily mean $\mathrm{NH}_{3}$ concentration at the study site $\left(0.50 \mu \mathrm{g} \mathrm{N} \mathrm{m}^{-3}, 27 \mathrm{~m}\right.$ height$)$ was much lower than those found in some forests affected by $\mathrm{NH}_{3}$-rich air, e.g., the 2-year mean at a Douglas fir forest in The Netherlands (4.3 $\mu \mathrm{g} \mathrm{N} \mathrm{m}^{-3}$; Wyers and Erisman, 1998) and the summer-mean at a montane-subalpine forest in Colorado, USA ( $3.4 \mu \mathrm{g} \mathrm{N} \mathrm{m}^{-3}$; Langford and Fehsen- 

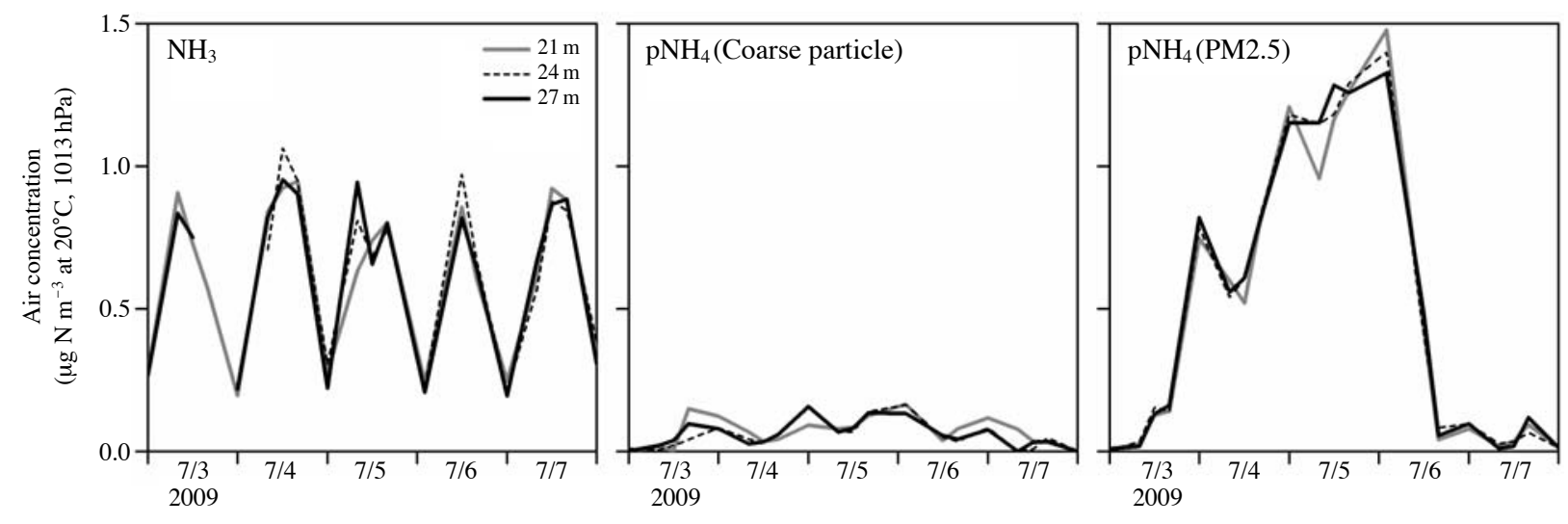

Fig. 2. Air concentrations of $\mathrm{NH}_{3}$ and particulate ammonium.

Table 1. Mean air concentrations of $\mathrm{NH}_{3}$ and $\mathrm{pNH}_{4}$ during the research period ${ }^{\mathrm{a}}$.

\begin{tabular}{cccc}
\hline Time & $\begin{array}{c}\mathrm{NH}_{3} \\
\mu \mathrm{g} \mathrm{N} \mathrm{m}^{-3}\end{array}$ & $\begin{array}{c}\mathrm{pNH}_{4} \\
(\text { Coarse particles }) \\
\mu \mathrm{g} \mathrm{N}^{-3}\end{array}$ & $\begin{array}{c}\mathrm{pNH}_{4} \\
\left(\mathrm{PM} \mathrm{N} \mathrm{m}^{-3}\right.\end{array}$ \\
\hline $\begin{array}{c}\mu \mathrm{g} \mathrm{N} \text { meight } \\
\text { Daytime }\end{array}$ & $0.77(0.20)$ & $0.06(0.04)$ & $0.53(0.52)$ \\
Nighttime & $0.24(0.05)$ & $0.07(0.07)$ & $0.57(0.61)$ \\
Day & $0.50(0.20)$ & $0.07(0.08)$ & $0.55(0.80)$ \\
24 m height & & & \\
Daytime & $0.74(0.23)$ & $0.05(0.05)$ & $0.53(0.52)$ \\
Nighttime & $0.28(0.07)$ & $0.08(0.07)$ & $0.58(0.63)$ \\
Day & $0.51(0.24)$ & $0.07(0.08)$ & $0.55(0.82)$ \\
21 m height & & & \\
Daytime & $0.75(0.20)$ & $0.07(0.05)$ & $0.51(0.51)$ \\
Nighttime & $0.26(0.05)$ & $0.08(0.07)$ & $0.59(0.66)$ \\
Day & $0.51(0.20)$ & $0.05(0.08)$ & $0.55(0.83)$ \\
\hline
\end{tabular}

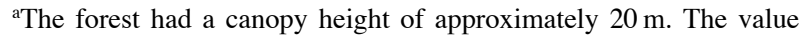
for "Day" denotes the average of the daytime and nighttime. Numbers in parentheses are the standard deviations.

feld, 1992), whereas it was similar to those of some rural forests, e.g., two field campaigns conducted in spring at a secondary broadleaf forest occasionally affected by animal husbandry activities in Indiana, USA (0.5-1.0 $\mu \mathrm{g} \mathrm{N} \mathrm{m}^{-3}$; Pryor et al., 2001), the 5year mean at a Norway spruce forest surrounded by agricultural lands in western Jutland, Denmark (0.66 $\mu \mathrm{g} \mathrm{N} \mathrm{m}^{-3}$; Andersen et al., 1999), and the 3-year mean at a Norway spruce forest in a forested rural area in Saxony, Germany $\left(0.44 \mu \mathrm{g} \mathrm{N} \mathrm{m}^{-3}\right.$; Zimmermann et al., 2006). However, the daily mean $\mathrm{NH}_{3}$ concentration was higher than that in fairly remote forests, e.g., the 2-year mean of a snowless season at a young larch forest in northernmost Hokkaido, Japan $(0.31 \mu \mathrm{g} \mathrm{N}$ $\mathrm{m}^{-3}, 30 \mathrm{~m}$ height; Hayashi et al., 2009a) and the summer-mean at a remote hardwood forest in central USA

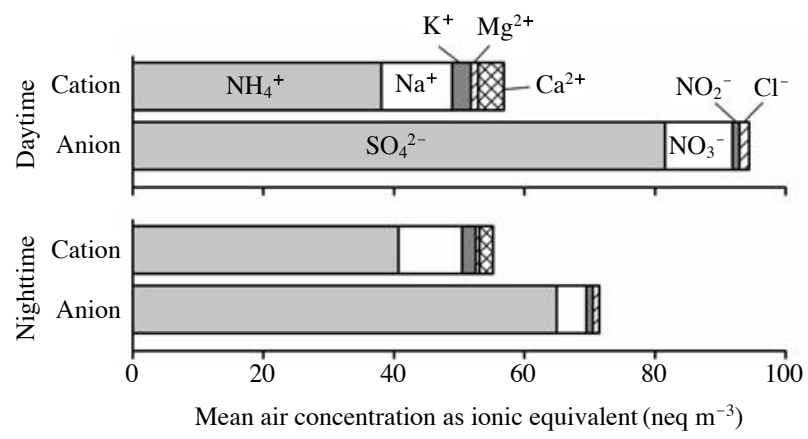

Fig. 3. Mean ionic compositions of PM2.5 in the daytime and nighttime during the research period at a height of $27 \mathrm{~m}$ from the ground surface.

(0.17 $\mu \mathrm{g} \mathrm{N} \mathrm{m}^{-3}$; Langford et al., 1992). The site of the present study had the characteristics of a forested rural area with respect to its summer-mean $\mathrm{NH}_{3}$ concentration, although the site was a subalpine forest affected little by direct human activities.

The daytime and nighttime means of PM2.5 ammonium concentration $(27 \mathrm{~m}$ height $)$ were $0.53 \pm 0.52$ and $0.57 \pm 0.61 \mu \mathrm{g} \mathrm{N} \mathrm{m}^{-3}$, respectively (Table 1). The daily mean PM2.5 ammonium concentration at the study site $\left(0.55 \mu \mathrm{g} \mathrm{N} \mathrm{m}^{-3}, 27 \mathrm{~m}\right.$ height $)$ was lower than the 3-year mean at a Norway spruce forest in a forested rural area in Saxony, Germany $\left(1.2 \mu \mathrm{g} \mathrm{N} \mathrm{m}^{-3}\right.$; Zimmermann et al., 2006), but it was higher than the 2-year mean of a snowless season at a young larch forest in northernmost Hokkaido, Japan $(0.29 \mu \mathrm{g} \mathrm{N}$ $\mathrm{m}^{-3}, 30 \mathrm{~m}$ height; Hayashi et al., 2009a).

Fig. 3 shows the mean ionic compositions of PM2.5 (27 $\mathrm{m}$ height); the compositions were similar regardless of the measurement height (data not shown). The major components were ammonium and sulfate for cations and anions, respectively. The very high corre- 

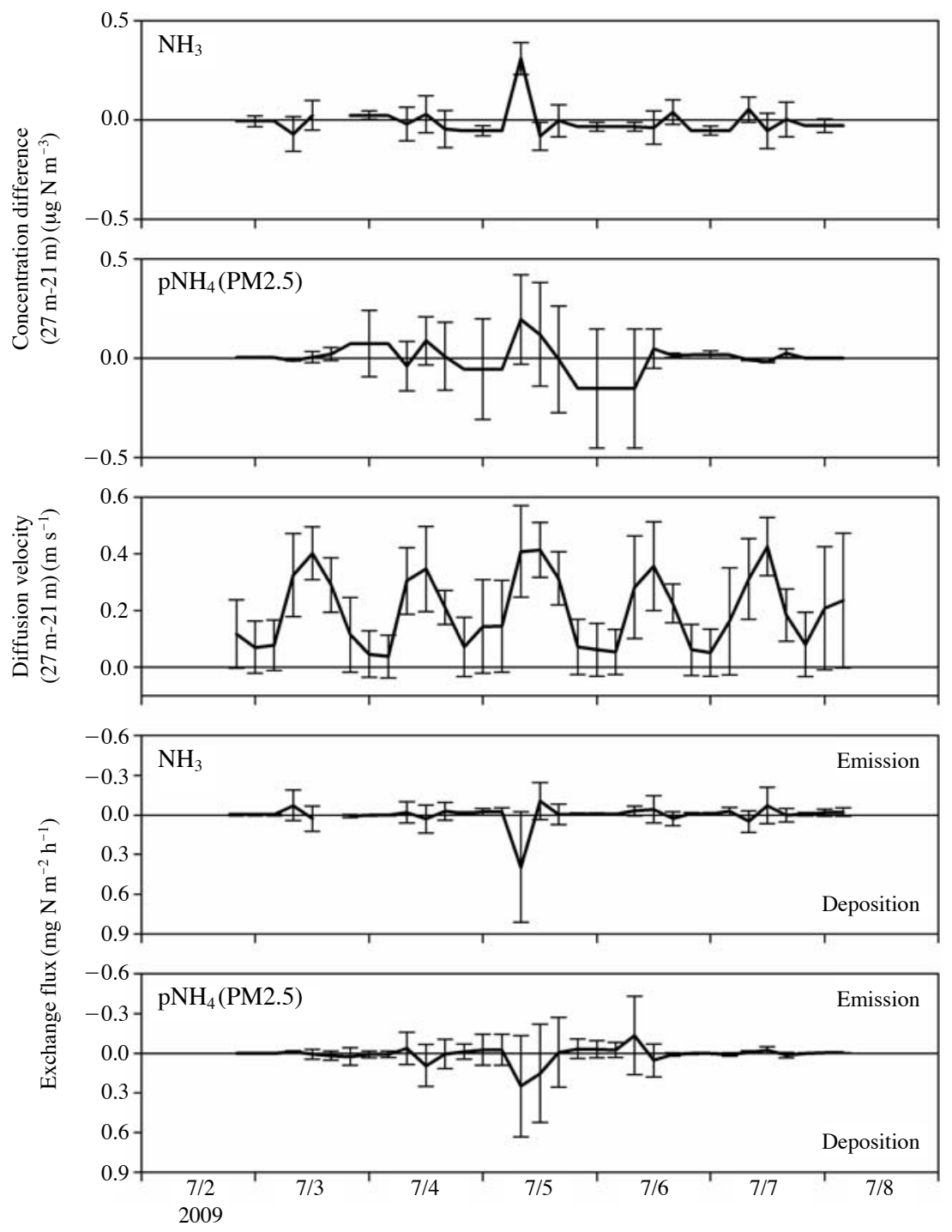

Fig. 4. Concentration differences, diffusion velocities, and exchange fluxes of $\mathrm{NH}_{\mathrm{x}}$ between the heights of 21 and $27 \mathrm{~m}$ from the ground surface. Vertical bars denote standard deviations.

lation between the PM2.5 ammonium and PM2.5 sulfate concentrations $(R=0.957,27 \mathrm{~m}$ height, $n=20)$ suggests that PM2.5 ammonium condensed mainly with PM2.5 sulfate. The equivalent sums of anions exceeded those of cations in both the daytime and the nighttime (Fig. 3). Most of the difference between anions and cations probably corresponds to protons, which indicates that PM2.5 was acidic and that ammonium bisulfate was a major component of PM2.5 ammonium as well as ammonium sulfate.

\section{3 Exchange Fluxes}

Fig. 4 shows $\Delta c$ (before correction by the actual air temperature and air pressure), $D$, and the exchange flux between the heights of 21 and $27 \mathrm{~m}$. Positive and negative values of exchange flux denote downward and upward fluxes, respectively.

The exchange fluxes of $\mathrm{NH}_{\mathrm{x}}$ were bidirectional (Fig. 4 ), although the derived fluxes had a certain amount of uncertainty (Section 2.4). Both the maximum and minimum values occurred in the daytime, i.e., 0.39 $\mathrm{mg} \mathrm{N} \mathrm{m}{ }^{-2} \mathrm{hr}^{-1}$ of downward flux and $0.11 \mathrm{mg} \mathrm{N} \mathrm{m}^{-2}$ $\mathrm{hr}^{-1}$ of upward flux for $\mathrm{NH}_{3}$ and $0.25 \mathrm{mg} \mathrm{N} \mathrm{m}^{-2} \mathrm{hr}^{-1}$ of downward flux and $0.13 \mathrm{mg} \mathrm{N} \mathrm{m}^{-2} \mathrm{hr}^{-1}$ of upward flux for PM2.5 ammonium. The exchange fluxes of $\mathrm{NH}_{\mathrm{x}}$ in the nighttime were relatively small (Fig. 4), with a range between $0.01 \mathrm{mg} \mathrm{N} \mathrm{m}^{-2} \mathrm{hr}^{-1}$ of downward flux and $0.03 \mathrm{mg} \mathrm{N} \mathrm{m}^{-2} \mathrm{hr}^{-1}$ of upward flux for $\mathrm{NH}_{3}$ and between $0.03 \mathrm{mg} \mathrm{N} \mathrm{m}^{-2} \mathrm{hr}^{-1}$ of downward flux and $0.03 \mathrm{mg} \mathrm{N} \mathrm{m}^{-2} \mathrm{hr}^{-1}$ of upward flux for PM2.5 
ammonium. The small fluxes at night resulted from the decreases in both $\Delta c$ and $D$ (Fig. 4). The exchange fluxes of $\mathrm{NH}_{\mathrm{x}}$ at night can be considered as zero, with a certain degree of uncertainty because of their very small magnitude.

Both $\mathrm{NH}_{3}$ and PM2.5 ammonium had remarkably large downward fluxes on the morning of 5 July 2009, i.e., 0.39 and $0.25 \mathrm{mg} \mathrm{N} \mathrm{m}^{-2} \mathrm{hr}^{-1}$, respectively. These large downward fluxes originated primarily from a large $\Delta c$ (Fig. 4) and, secondarily, from a large $D$ (Fig. 4) induced by a large $u_{*}$ (Fig. 1). For reference, $\mathrm{SO}_{2}$ had a similarly large $\Delta c$, but sulfate had a near-zero $\Delta c$ (data not shown). The deposition velocity $\left(V_{d}\right)$ as a net value was calculated by dividing the exchange flux by the air concentration at a height of $27 \mathrm{~m}$. The large downward fluxes corresponded to remarkably large $V_{d}$ values of 13.5 and $6.9 \mathrm{~cm} \mathrm{~s}^{-1}$ for $\mathrm{NH}_{3}$ and PM2.5 ammonium, respectively. For reference, Wyers et al. (1992) and Zimmerman et al. (2006) reported similar mean $V_{d}$ values of $\mathrm{NH}_{3}$ for forests, i.e., 3.2 and $3.33 \mathrm{~cm} \mathrm{~s}^{-1}$, respectively. It appears that the showers during the night of 3 to 4 July 2009 (Fig. 1) thoroughly washed and wetted the forest canopy and ground surface, and the subsequent clear sky on the morning of 5 July 2009, which is indirectly shown in the steep decrease in relative humidity (Fig. 1), stimulated convection. Both are necessary conditions to accelerate the dry deposition of $\mathrm{NH}_{3}$, particularly, surface deposition on not only the leaf surface but also other tree bodies such as branches and bark. In addition, the arithmetic mean of $V_{d}$ during the research period was almost zero for both $\mathrm{NH}_{3}$ and PM2.5 ammonium. Therefore, the $\mathrm{NH}_{\mathrm{x}}$ exchange between the study forest and the atmosphere seems to be balanced.

Wyers and Erisman (1998) have reported the reevaporation of $\mathrm{NH}_{3}$ from $\mathrm{NH}_{\mathrm{x}}$ previously deposited on the leaf surface; however, only a weak upward flux of $\mathrm{NH}_{3}$ following the remarkably large deposition of $\mathrm{NH}_{\mathrm{x}}$ on 5 July 2009 was found in the present study (Fig. 4). The drizzle on 6 July 2009 might have rinsed off the deposited $\mathrm{NH}_{\mathrm{x}}$ on the leaf surface, effectively reducing the re-evaporation. Thus, the cleaning effect as well as the surface wetness by rainfall should be monitored to evaluate and generalize the gas and particle exchange at a forest.

With respect to the large $V_{d}$ of PM2.5 ammonium, a $V_{d}$ of aerosols based on a field measurement at a forest tends to be larger than a $V_{d}$ derived from a theoretical model (e.g., Matsuda et al., 2010; Horváth, 2003; Garland, 2001; Erisman et al., 1997). Furthermore, the clear decrease in the air concentration of $\mathrm{NH}_{3}$ near the canopy on the morning of 5 July 2009 (Fig. 2) was probably due to enhanced dry deposition, which might induce the evaporation of PM2.5 ammonium via a particle-to-gas conversion to compensate for the decreased $\mathrm{NH}_{3}$ concentration. The simultaneous decrease in the air concentration of PM2.5 ammonium near the canopy (Fig. 2) supports this interpretation, in which the large downward flux of PM2.5 ammonium should be attributable to the apparent emission of $\mathrm{NH}_{3}$ (Section 3.4) to a certain extent.

However, ammonium sulfate and ammonium bisulfate, i.e., the most dominant salts in the present study (Fig. 3), have low vapor pressures. Therefore, these particles were unlikely to contribute to any particleto-gas conversion. Meanwhile, both nitrate and chloride had very low concentrations (Fig. 3), and they were also unlikely to be a main source of any particleto-gas conversion. The counter anion of the PM2.5 ammonium that vaporized was unidentified.

The causes of the upward flux of $\mathrm{NH}_{3}$ occasionally found in the daytime (Fig. 4) are divided into direct emissions from the study forest and apparent emissions due to particle-to-gas conversion (Section 3.4). By contrast, the cause of the upward flux of PM2.5 ammonium should be gas-to-particle conversion (Section 3.4) because PM2.5 is mainly secondary particles and direct emissions from a forest are unlikely to occur.

\section{3. $4 \mathrm{NH}_{3}$ Emission from and Deposition to the Forest}

A forest can emit $\mathrm{NH}_{3}$ from stomata, leaf surfaces, and soil surfaces (Hayashi et al., 2009a; Neirynck and Ceulemans, 2008; Andersen et al., 1999; Wyers and Erisman, 1998; Langford and Fehsenfeld, 1992). A forest in which trees and the understory are cut can also emit $\mathrm{NH}_{3}$ as a result of the decomposition of fresh organic matter (Hayashi et al., 2009a) in addition to volatilization after nitrogen fertilization. However, the study forest was a natural forest and thus not under management. Hence, the possible causes of $\mathrm{NH}_{3}$ emission from the study forest are limited to stomatal, leaf surface, and/or soil surface emissions.

Stomatal $\mathrm{NH}_{3}$ emission from a forest has been reported (Neirynck and Ceulemans, 2008; Andersen et al., 1999; Wyers and Erisman, 1998; Langford and Fehsenfeld, 1992). Stomatal $\mathrm{NH}_{3}$ emission is, however, limited to the daytime because of stomatal closure at night. Langford and Fehsenfeld (1992) reported an average value of the compensation point of $0.8 \mathrm{ppb}$ $\left(=0.48 \mu \mathrm{g} \mathrm{N} \mathrm{m}^{-3}\right)$ for a remote natural forest in the central USA. All air concentrations of $\mathrm{NH}_{3}$ in the daytime in the present study exceeded this value (Fig. 2 ), which suggests that stomatal $\mathrm{NH}_{3}$ emissions were not likely to occur in the study forest. However, the difference in tree species between Japan and the USA should be noted.

Leaf-surface $\mathrm{NH}_{3}$ emissions might occur in a forest 
(Neirynck and Ceulemans, 2008; Wyers and Erisman, 1998) when the $\mathrm{NH}_{3}$ originates from $\mathrm{NH}_{\mathrm{x}}$ that previously deposited on the leaf surface. The accumulated $\mathrm{NH}_{3}$ might be reemitted to the atmosphere in conjunction with a subsequent dry period, which is the daytime in many cases (Wyers and Erisman, 1998). Leaf-surface emissions, including emissions from other tree bodies, might contribute to the emission of $\mathrm{NH}_{3}$ following the remarkably large deposition of $\mathrm{NH}_{3}$ on the morning of 5 July, 2009 (Fig. 4), in addition to the apparent emission as described later. The relatively low air concentrations of $\mathrm{NH}_{3}$ (Fig. 2, Table 1) were advantageous to inducing leaf-surface $\mathrm{NH}_{3}$ emissions.

In terms of soil-surface $\mathrm{NH}_{3}$ emissions, the $\mathrm{pH}$ values of rainwater and the soil solution at a depth of $10 \mathrm{~cm}$ at the study site were $4-5$ and less than 6 , respectively (Ikeda et al., 2004). Soil-surface $\mathrm{NH}_{3}$ emissions are unlikely to be significant under such acidic conditions (Hayashi et al., 2008).

As described above, leaf-surface $\mathrm{NH}_{3}$ emission was the only possible direct emission process of $\mathrm{NH}_{3}$ in the study forest, other than the apparent emission due to gas-particle interconversion discussed below.

When a forest emits $\mathrm{NH}_{3}$, the emitted $\mathrm{NH}_{3}$ encounters acidic substances, e.g., sulfuric acid and nitric acid, in the atmosphere near the canopy and can condense with acidic substances to form PM2.5 ammonium. This process results in the apparent emission of PM2.5 ammonium, which simultaneously and apparently decreases the emission flux of $\mathrm{NH}_{3}$. The upward flux of PM2.5 ammonium occasionally shown in the daytime (Fig. 4) was perhaps attributable to this apparent emission.

Meanwhile, evaporable ammonium salts, such as ammonium nitrate, release $\mathrm{NH}_{3}$ due to their evaporation in the atmosphere with a temperature rise (e.g., Pryor et al., 2001). Evaporation near the canopy is likely to occur in the daytime in good weather because of the warming effect of solar radiation on the canopy. In this case, the tendency for deposition of PM2.5 is enhanced but that of $\mathrm{NH}_{3}$ is weakened and even turns into an emission tendency in some cases. Furthermore, a portion of ammonium salts might evaporate to compensate for the decrease in the air concentration of $\mathrm{NH}_{3}$ when a large amount of $\mathrm{NH}_{3}$ deposition occurs (Section 3.3). However, the evaporation of ammonium salts does not seem to be very strong in the study forest because the main component of PM2.5 was ammonium sulfate (Fig. 3), which has a low vapor pressure.

\section{CONCLUSIONS}

The air concentrations and exchange fluxes of $\mathrm{NH}_{\mathrm{x}}$ were investigated at a subalpine deciduous forest in central Japan during a summer week. The $\mathrm{NH}_{3}$ concentrations (daily mean of $0.50 \mu \mathrm{g} \mathrm{N} \mathrm{m}^{-3}$ ) showed a clear circadian variation with a nearly constant amplitude, high in the daytime $\left(0.77 \mu \mathrm{g} \mathrm{N} \mathrm{m}^{-3}\right.$ on average $)$ and low at night $\left(0.24 \mu \mathrm{g} \mathrm{N} \mathrm{m}^{-3}\right.$ on average). The concentrations of $\mathrm{pNH}_{4}$ for coarse fractions were very low $\left(0.07 \mu \mathrm{g} \mathrm{N} \mathrm{m}^{-3}\right.$ as the daily mean). By contrast, those for PM2.5 ammonium were relatively high $(0.55 \mu \mathrm{g}$ $\mathrm{N} \mathrm{m}^{-3}$ as the daily mean), and the concentration pattern of PM2.5 ammonium had a longer cycle than a circadian variation, which was remarkably similar to that of PM2.5 sulfate and might be related to the longrange transport of PM2.5. In comparison with the early studies done in North America and Europe, the study site had features characteristic of a forested rural area with respect to the summer-mean $\mathrm{NH}_{3}$ concentration. The PM2.5 at the study site was composed mainly of ammonium ions and sulfate ions. The PM2.5 was generally acidic.

The exchange fluxes of $\mathrm{NH}_{\mathrm{x}}$ in the daytime were bidirectional, but those at night could be considered as zero because of their very small magnitude. However, for PM2.5 ammonium in particular, changes in the status of long-range transportation might affect the air concentrations and the exchange fluxes at the study forest. Both $\mathrm{NH}_{3}$ and PM2.5 ammonium had remarkably large downward fluxes on the morning of 5 July 2009 , i.e., 0.39 and $0.25 \mathrm{mg} \mathrm{N} \mathrm{m}^{-2} \mathrm{hr}^{-1}$, respectively, which corresponded to $V_{d}$ values of 13.5 and $6.9 \mathrm{~cm} \mathrm{~s}^{-1}$, respectively. The large $V_{d}$ is probably attributable to the preceding rainfall that washed and wetted the forest canopy and the strong convection in the morning. However, the mean $V_{d}$ during the research period was almost zero for both $\mathrm{NH}_{3}$ and PM2.5 ammonium. The atmosphere-forest exchange of $\mathrm{NH}_{\mathrm{x}}$ at the study forest is likely balanced.

The possible cause of the upward fluxes of $\mathrm{NH}_{3}$ occasionally found at the study forest was limited to leaf-surface emissions. The air concentrations of $\mathrm{NH}_{3}$ in the daytime most likely exceed the compensation point of $\mathrm{NH}_{3}$, resulting in dry deposition through stomata instead of stomatal emission. The relatively low $\mathrm{pH}$ value of the soil solution at the study forest should inhibit soil emissions of $\mathrm{NH}_{3}$ as well.

In terms of the gas-particle interconversion at the study forest, which induces an apparent emission/deposition of $\mathrm{NH}_{\mathrm{x}}$, the upward fluxes of PM2.5 ammonium occasionally found in the daytime might be attributable to the apparent emission of PM2.5 ammonium due to the condensation of $\mathrm{NH}_{3}$ emitted from the canopy. Meanwhile, the contribution of the evaporation of ammonium salts, which results in an apparent deposition of PM2.5 ammonium, is unlikely to be impor- 
tant at the study forest because the PM2.5 was composed mainly of ammonium sulfate, which has a low vapor pressure.

\section{ACKNOWLEDGEMENTS}

We would like to express our gratitude to Prof. Shiro Hatakeyama and Prof. Takeshi Izuta, Tokyo University of Agriculture and Technology, Japan, for their support of the present study. The authors also thank Mr. Yoshifumi Fujimura, Mr. Takashi Miyake, and Mr. Masayuki Miyanaga, Meisei University, Japan, for their assistance with measurements and chemical analyses. This study was supported by a Grant-in-Aid for Scientific Research on Innovative Areas, No. 20120012, provided by the Ministry of Education, Culture, Sports, Science, and Technology, Japan.

\section{REFERENCES}

Andersen, H.V., Hovmand, M.F., Hummelshoj, P., Jensen, N.O. (1999) Measurements of ammonia concentrations, fluxes and dry deposition velocities to a spruce forest 1991-1995. Atmospheric Environment 33, 1367-1383.

Anlauf, K.G., Fellin, P., Wiebe, H.A., Schiff, H.I., Mackay, G.I., Braman, R.S., Gilbert, R. (1985) A comparison of three methods for measurement of atmospheric nitric acid and aerosol nitrate and ammonium. Atmospheric Environment 19, 325-333.

Bardouki, H., Liakakou, H., Economou, C., Sciare, J., Smolík, J., Ždímal, V., Eleftheriadis, K., Lazaridis, M., Dye, C., Mihalopoulos, N. (2003) Chemical composition of size-resolved atmospheric aerosols in the eastern Mediterranean during summer and winter. Atmospheric Environment 37, 195-208.

Bouwman, A.F., van Vuuren, D.P., Derwent, R.G., Posch, M. (2002) A global analysis of acidification and eutrophication of terrestrial ecosystems. Water, Air, and Soil Pollution 141, 349-382.

Businger, J.A. (1986) Evaluation of the accuracy with which dry deposition can be measured with current micrometeorological techniques. Journal of Climate and Applied Meteorology 25, 1100-1124.

EMEP (2001) EMEP manual for sampling and chemical analysis. EMEP/CCC-Report 1/95. Available from: http://www.emep.int/.

Erisman, J.W., Draaijers, G.P.J. (1995) Atmospheric deposition in relation to acidification and eutrophication, Studies in Environmental Science 63, Elsevier, 55-75.

Erisman, J.W., Draaijers, G., Duyzer, J., Hofshreuder, P., van Leeuwen, N.F.M., Römer, F., Ruijgrok, W., Wyers, P., Gallagher, M. (1997) Particle deposition to forestssummary of results and application. Atmospheric Environment 31, 321-332.

Erisman, J.W., Schaap, M. (2004) The need for ammonia abatement with respect to secondary PM reductions in Europe. Environmental Pollution 129, 159-163.

Galloway, J.N., Dentener, F.J., Capone, D.G., Boyer, E.W., Howarth, R.W., Seitzinger, S.P., Asner, G.P., Cleveland, C.C., Green, P.A., Holland, E.A., Karl, D.M., Michaels, A.F., Porter, J.H., Townsend, A.R., Vörösmarty, C.J. (2004) Nitrogen cycles: past, present, and future. Biogeochemistry 70, 153-226.

Garland, J.A. (2001) On the size dependence of particulate deposition. Water, Air and Soil Pollution: Focus 1, 323332.

Hayashi, K., Komada, M., Miyata, A. (2007) Atmospheric deposition of reactive nitrogen on turf grassland in central Japan: Comparison of the contribution of wet and dry deposition. Water, Air, and Soil Pollution: Focus 7, 119-129.

Hayashi, K., Koga, N., Yanai, Y. (2009b) Effects of fieldapplied composted cattle manure and chemical fertilizer on ammonia and particulate ammonium exchanges at an upland field. Atmospheric Environment 43, 57025707.

Hayashi, K., Nishimura, S., Yagi, K. (2008) Ammonia volatilization from a paddy field following applications of urea: Rice plants are both an absorber and an emitter for atmospheric ammonia. Science of the Total Environment 390, 485-494.

Hayashi, K., Takagi, K., Noguchi, I., Fukuzawa, K., Takahashi, H., Fukazawa, T., Shibata, H., Fujinuma, Y. (2009a) Ammoniacal nitrogen emission from a young larch ecosystem afforested after clear-cutting of a pristine forest in northernmost Japan. Water, Air, and Soil Pollution 200, 33-46.

Hayashi, K., Yan, X.Y. (2010) Airborne nitrogen load in Japanese and Chinese agroecosystems. Soil Science and Plant Nutrition 56, 2-18.

Horváth, L. (2003) Dry deposition velocity of PM2.5 ammonium sulfate particles to a Norway spruce forest on the basis of S- and N-balance estimations. Atmospheric Environment 37, 4419-4424.

Ikeda, H., Yasuike, S., Kobayashi, T., Nakaya, K., Suzuki, C. (2004) Carbon stock and chemistry in deciduous forest-soil system. CRIEPI Research Report, Central Research Institute of Electric Power Industry, Japan, U03069, 19p (in Japanese with English abstract).

IPCC (2007) The Physical Science Basis. Contribution of Working Group I to the Fourth Assessment Report of Intergovernmental Panel on Climate Change. Cambridge University Press, Cambridge.

Keck, L., Wittmaack, K. (2005) Effect of filter type and temperature on volatilization losses from ammonium salts in aerosol matter. Atmospheric Environment 39, 4093-4100.

Langford, A.O., Fehsenfeld, F.C. (1992) Natural vegetation as a source or sink for atmospheric ammonia: a case study. Science 25, 581-583.

Langford, A.O., Fehsenfeld, F.C., Zachariassen, J., Schimel, D.S. (1992) Gaseous ammonia fluxes and background concentrations in terrestrial ecosystems of the 
United States. Global Biogeochemical Cycles 6, 459483.

Matson, P., Lohse, K.A., Hall, S.J. (2002) The globalization of nitrogen deposition: Consequences for terrestrial ecosystems. Ambio 31, 113-119.

Matsuda, K., Fujimura, Y., Hayashi, K., Takahashi, A., Nakaya, K. (2010) Deposition velocity of PM2.5 sulfate in the summer above a deciduous forest in central Japan. Atmospheric Environment 44, 4582-4587.

Miyata, A. (2001) Observational study on methane exchange between wetland ecosystems and the atmosphere. Bulletin of National Institute for Agro-Environmental Sciences, 19, 61-183. Available from: http://www.niaes. affrc.go.jp/index_e.html.

Nakaya, K. (2008) Study of improvement on evaluation method of energy and mass exchange between atmosphere and forest ecosystem. Memories of the Research Faculty of Agriculture, Hokkaido University 29, 149213 (in Japanese with English abstract).

Neirynck, J., Ceulemans, R. (2008) Bidirectional ammonia exchange above a mixed coniferous forest. Environmental Pollution 154, 424-438.

Nemitz, E., Sutton, M.A. (2004) Gas-particle interactions above a Dutch heathland: III. Modelling the influence of the $\mathrm{NH}_{3}-\mathrm{HNO}_{3}-\mathrm{NH}_{4} \mathrm{NO}_{3}$ equilibrium on size-segregated particle fluxes. Atmospheric Chemistry and Physics 4, 1025-1045.

Nemitz, E., Sutton, M.A., Wyers, G.P., Otjes, R.P., Mennen, M.G., van Putten, E.M., Gallagher, M.W. (2004) Gas-particle interactions above a Dutch heathland: II. Concentrations and surface exchange fluxes of atmospheric particles. Atmospheric Chemistry and Physics 4, 1007-1024.

Neuberger, M., Schimek, M.G., Horak, Jr. F., Moshammer, H., Kundi, M., Frischer, T., Gomiscek, B., Puxbaum, H., Hauck, H., AUPHEP-Team (2004) Acute effects of particulate matter on respiratory diseases, symptoms and functions: epidemiological results of the Austrian project on health effects of particulate matter (AUPHEP). Atmospheric Environment 38, 3971-3981.
Niemi, J.V., Saarikoski, S., Aurela, M., Tervahattu, H., Hillamo, R., Westphal, D.L., Aarnio, P., Koskentalo, T., Makkonen, U., Vehkamaki, H., Kulmala, M. (2009) Long-range transport episodes of fine particles in southern Finland during 1999-2007. Atmospheric Environment 43, 1255-1264.

Pryor, S.C., Barthelmie, R.J., Sørensen, L.L., Jensen, B. (2001) Ammonia concentrations and fluxes over a forest in the midwestern USA. Atmospheric Environment 35, 5645-5656.

Saigusa, N., Yamamoto, S., Murayama, S., Kondo, H., Nishimura, N. (2002) Gross primary production and net ecosystem exchange of a cool-temperate deciduous forest estimated by the eddy covariance method. Agricultural and Forest Meteorology 112, 203-215.

Sickles II, J.E., Hodson, L.L., Vorburger, L.M. (1999) Evaluation of the filter pack for long-duration sampling of ambient air. Atmospheric Environment 33, 21872202.

van Oss, R., Duyzer, J.H., Wyers, P. (1998) The influence of gas-to-particle conversion on measurements of ammonia exchange over forest. Atmospheric Environment 32, 465-471.

Wyers, G.P., Duyzer, J.H. (1997) Micrometeorological measurement of the dry deposition flux of sulphate and nitrate aerosols to coniferous forest. Atmospheric Environment 31, 333-343.

Wyers, G.P., Erisman, J.W. (1998) Ammonia exchange over coniferous forest. Atmospheric Environment 32, 441-451.

Wyers, G.P., Vermeulen, A.T., Slanina, J. (1992) Measurement of dry deposition of ammonia on a forest. Environmental Pollution 75, 25-28.

Zimmermann, F., Plessow, K., Queck, R., Bernhofer, C., Matschullat, J. (2006) Atmospheric N- and S-fluxes to a spruce forest: Comparison of inferential modelling and the throughfall method. Atmospheric Environment 40, 4782-4796.

(Received 6 January 2011, accepted 25 May 2011) 